\title{
Analysis of the Association between Public Health and Drug Market Policing: Review of Law Enforcement Indicators
}

\author{
PETRUŽELKA, B., BARTÁK, M.
}

Charles University, First Faculty of Medicine, and General University Hospital in Prague, Department of Addictology, Czech Republic
Citation | Petruželka, B., Barták, M. (2019). Analysis of the Association between Public Health and Drug Market Policing: Review of Law Enforcement Indicators. Adiktologie, 1911), 43-51; https://doi.org/10.35198/01-2019-001-0005
BACKGROUND: A number of studies show that an intensification of the policing of illicit drug markets has an impact on public health. The impacts are largely seen as negative. AIMS: The aim of this paper is to describe the basic characteristics of data collection and to review the aspects related to data collection and its context that might influence the law enforcement indicators (drug law offences and offenders). METHODS: This work is based on research on the literature and grey zone materials, which consisted of reviewing reports published by relevant institutions and by searching in specialized databases. RESULTS: Long-term indicators based on police statistics available for the Czech Republic come from the Crime Statistics System (ESSK) and from data collected by the National Drug Headquarters
(NPC). The difference between the ESSK and NPC data lies in the reporting procedures and their changes and specificity as regards the substances involved in drug law offences. The review identified different aspects of data collection and its context that have the potential to influence the indicators. Nine events with such potential were identified in three areas: legislation, the reporting system, and the structure and priorities. The events that have the greatest potential to influence the time series are related to the reporting system, structure, and priorities. CONCLUSIONS: The review may assist and facilitate informed analysis and interpretation of drug-related law enforcement indicators individually or in combination with other indicators, using time series analysis as well as comparative approaches.

Keywords | Indicator - Monitoring - Public health - Drug market policing - Drug law offences - Czech Republic 


\section{INTRODUCTION}

Supply control, which is one of the four pillars of the drug policy in the Czech Republic, is a body of legislative measures and law enforcement activities aimed at reducing or controlling the supply of addictive substances (Secretariat of the Government Council for Drug Policy Coordination, 2019). In this study, we focus on law enforcement, defined as "individuals and agencies responsible for enforcing laws and maintaining public order and public safety” (BJS, 2019). The activity and intensity of the enforcement of the drug law is measured by the number of drug law offences and arrests; see Cooper et al. (2005) and Friedman et al. (2011, 2006). Street-level policing, which is, in some cases, measured by the number of drug arrests, is the most frequently used indicator in studies focusing on the relationship between HIV prevention, treatment, and criminalization (DeBeck et al., 2017). Using drug law offences as a measure of the intensity of law enforcement in the Czech Republic, we can observe an 80\% increase between 2009 and 2014 (Zeman et al., 2017).

A number of studies have shown that an intensification of drug law enforcement leads to unwanted outcomes in many areas (Blankenship \& Koester, 2002; Bohnert et al., 2011; Booth et al., 2013; Burris et al., 2004; Cooper et al., 2005; Csete et al., 2016; DeBeck et al., 2017; Dixon \& Maher, 2005; Fitzgerald, 2005; Friedman et al., 2011, 2006; Kerr et al., 2005; Maher, 1999; Sarang et al., 2010; Small et al., 2006; Strathdee et al., 2010). The risk of HIV infection is shaped by environmental and structural factors, which are understudied (Strathdee et al., 2010). Among these factors are local policing practices and crackdowns, drug trafficking and distribution routes, police per capita, the enforcement of policies such as syringe access and exchange, and the laws governing possession of drugs and drug paraphernalia (ibid.). The DeBeck et al. (2017) review shows that the criminalization of drug use, including law enforcement, has a negative effect on HIV prevention and treatment. The report of the Johns Hopkins - Lancet Commission on Drug Policy and Health (Csete et al., 20016) identified negative effects of policing and incarceration on the transmission of infectious diseases, prevalence of overdoses, and barriers to services and treatment. A review of the impact of drug market enforcement on public health and the social context of drug use demonstrates that the impact is largely negative and includes worse access to healthcare services and an increase in risk behaviour in terms of communicable diseases and overdoses (Kerr et al., 2005).

The present authors did not find any quantitative studies in the Czech Republic that focused on the relationship between drug market policing and public health, but two qualitative studies exist. Increased drug market policing is described as police activity that leads to the arrest of a drug manufacturer or dealers (Minařík \& Zahradník, 2003). Such increased drug market policing has the potential to worsen access to healthcare services because the users are afraid of the police and, in addition to that, the trust between service providers and drug users decreases (ibid.). For example,
Minařík and Zahradník (2003) observed a decrease in the availability of sterile injecting equipment. Zábranský et al. (2001) observed an increase in risk behaviour on the part of drug users, worsened access to health services, and, in some cases, an increase in the incidence of hepatitis $\mathrm{C}$ roughly six months after an increase in drug market policing.

On the basis of the findings of foreign quantitative studies and qualitative studies from the Czech Republic, it is possible to assume that intensifying drug market policing, measured by the indicators of drug offences and drug arrests, i.e. records of police activity focused on drug markets, might have led to an increase in the public health indicators. To investigate this increase using quantitative methods, it is appropriate to use an analysis focused on trends, one of the main analytical approaches applied to routine or administrative indicators (Griffiths et al., 2000; Mounteney et al., 2010). In this case, we use a time series analysis. The goals of time series analysis are to identify patterns in the sequences of numbers over time (in this case, indicators), to test the impact of one or more interventions, and to forecast or compare series of different kinds of events (Tabachnick et al., 2019). For example, Gilmour et al. (2006) used time series analysis to investigate the health and social consequences of the Australian Heroin Shortage.

To conduct a time series analysis, it is necessary to have information on the changes in the data collection and to understand its potential impact on time series (Lopez Bernal et al., 2016). One assumption of a time series analysis is that the data is recorded in the same manner throughout the given time period (Gilmour et al., 2006). Another assumption is that the time series have enough time points and that the time series is complete (Tabachnick et al., 2019). These assumptions are related to the criteria of the validity and reliability of the indicators regarding trends, which, among others, include changes of context (institutions and policies) and local variability (Hartnoll et al., 1998). Furthermore, to conduct a time series analysis, it is important to consider rival explanations (Gilmour et al., 2006) and eventually include them into the research design. Although the number of drug law offences and arrests is used as the measure of drug market policing (see above), the question might be raised whether the factors related to the changes in drug-related crime played a significant part in the increase in drug law offences and whether the number of drug law offences does not rather represent the increase in drug-related crime. Drug-related crime in the Czech Republic has high latency; a significant portion of drug law offences are not recorded by the police, and, thus, the increase in the number of drug-related offences is reflective of the ability of the police to record such crime (Zeman et al., 2017). Furthermore, the increase in the number of problematic drug users was rather smaller compared to the rise in the number of drug law offences, and therefore it is not considered the main factor affecting the increase (ibid.) The conclusion that an increase in drug law offences is much more reflective of police activity rather than other factors is in line with the position of the NPC (2010) and with the body of literature that highlights the role of police resources and priorities in police statistics (Hart- 
noll et al., 1989; Loughran \& McCann, 2001; Mounteney, Fry, McKeganey, \& Haugland, 2010; Mounteney \& Griffiths, 2019; Mounteney \& Haugland, 2009;).

To undertake time series analysis of the relation between public health and law enforcement indicators, which the authors plan in a future study, it is necessary to have reviewed the basic information about the data collection and its context. A concise overview of this information focused on changes over time is not yet available in the Czech Republic. This paper focusing on the indicators of drug market policing is the first of two papers that cover this basic information, the second paper being focused on the public health indicators. The aim of this paper is to describe the basic characteristics of data collection and to review the aspects related to data collection and its context that might influence indicators of drug law offences and offenders. The added value of this review is not only for studies focusing on the relation between public health and policing but also for all those using trend data on Czech drug law offences and offenders. This review is also significant for a less structured interpretation of trends or for different analytical approaches using data collected over a certain time period. Furthermore, this review is relevant for international use of the policing indicators in the Czech Republic, because the information provided is not available for researchers without a command of the Czech language. For international comparison, which is one of the uses of these indicators, it is vital to have better information on the context of the indicators in different countries, which is usually unavailable (Kilmer et al., 2015).

\section{METHODS AND DATA SOURCES}

The main source of data for this article was a literature search. In the Czech Republic, the data on these indicators is based on the statistics of the Police Praesidium of the Czech Republic (ESSK) and the National Drug Headquarters of the Criminal Police and Investigation Service of the Police of the Czech Republic (NPC). The search focused on selected indicators of drug market policing: drug law offences (the number of registered criminal offences in the ESSK) and drug law offenders (the number of persons arrested in the NPC database, the number of persons prosecuted or investigated in the ESSK). We did not focus on the statistics for administrative offences. These are not used in other studies (Zeman et al., 2015; 2017) and the data is not available for longer periods from all the regions. The national drug reports make available the data starting from 2015 (Mravčík et al., 2018) and the regional reports (Kiššová et al., 2014) are available starting from 2012; however, not all regions have been reporting the number of drug-related administrative offences continuously and, thus, this data is not suitable for a national trend analysis. During the search we were looking for the following information about indicators of drug law offences and drug law offenders: the availability of specific data sets, characteristics of the data collection and its context that might influence the data collection, and changes in these aspects over time.
Since the bulk of the relevant literature consists of "grey literature" - in the form of various reports that are not archived in scientific databases and that are published by various institutions working in the relevant area - the literature search consisted mainly of reviewing final reports published by such institutions and searches in scientific databases. The reports of the following institutions were reviewed: the Police of the Czech Republic and its subsidiary organizations - primarily the NPC, the Czech National Monitoring Centre for Drugs and Addiction (NMS), the Department of Addictology of the First Faculty of Medicine of Charles University in Prague and the General University Hospital in Prague, and the Institute of Criminology and Social Prevention. The most comprehensive source of information used in this analysis is the Annual Reports on the Drug Situation in the Czech Republic published by the NMS. The search in scientific databases was conducted in the Web of Science Core Collection and Scopus (keywords: Czech*, drug-related crime, drug market policing, drug law offence, drug law offenders, drug law enforcement, drug law enforcement indicators). Furthermore, the online archives of the Adiktologie journal and the Czech Criminology Review were searched. The literature search was only complemented by discussions and email conversations with relevant experts if the information provided in the reports was not clear.

\section{RESULTS}

\subsection{Availability of the data}

Indicators of drug law offences and of drug law offenders are available at the international level. These indicators are not among the five key EMCDDA indicators, but they are regularly presented in the Statistical Bulletins (EMCDDA, 2018), and they are also included in the European Sourcebook (Aebi et al., 2014). At the national level, data from both sources is included in national reports on the drug situation (Mravčík et al., 2018). NPC data is available in annual reports (National Drug Headquarters, 2018) and data from the ESSK is available in crime statistics and overviews (Police of the Czech Republic, 2018a) and in the form of an interactive map (Otevřená společnost, 2018a). Furthermore, it is possible to request the disaggregated data from the NPC and the Police Directorate of the Czech Republic.

\subsection{Data collection characteristics: general police (ESSK) and NPC database}

The data is collected in two basic data collection systems; however, both systems are based in the Police of the Czech Republic. The ESSK is focused on all types of crime, while the NPC database is focused specifically on drug-related crime. The process of data collection is slightly different. The NPC database is managed by the National Drug Headquarters, while the ESSK is the general and central database of the Police.

The basic definition of the subject of interest for both the police and monitoring and research activities is "primary drug 
crime", violation of the national laws and regulations in the area of the control of narcotic and psychotropic substances (Mravčík et al., 2014; Zeman \& Gajdošíková, 2010). It is also referred to as drug law offences, offences against the national drug legislation (EMCDDA, 2019). Currently, the concept of drug law offences includes the crime categories defined by Act No. 40/2009 Coll., the Penal Code: Sections 283 (Unauthorized production and other handling of narcotic and psychotropic substances and poisons), 284 (Possession of a narcotic or psychotropic substance or poison), 285 (Unauthorized cultivation of plants containing a narcotic or psychotropic substance), 286 (Manufacturing and possession of an article for the unauthorized production of a narcotic or psychotropic substance or poison), 287 (Promotion of drug use) (Mravčík et al., 2014).

The ESSK is the basic source of information for crime analyses and has been in operation since 1973 (Marešová, 2011). The information is fed into the database from other databases that are filled in by police officers during criminal proceedings. Currently, the information is entered into the system of records of criminal proceedings, from which it is then automatically copied into individual police information systems, which form the basis of the ESSK database (Přecechtěl, 2013). Criminal acts are recorded following information reported by the public or on the basis of a police investigation. The basic units used in the ESSK are the criminal act and the perpetrator (Marešová, 2011). The number of drug law offenders is the number of persons prosecuted or investigated. A police expert confirmed in an email that the police keep track of criminal acts solved in a given year if the criminal investigation was opened in that year. Criminal acts are reported on the level of the police unit responsible for the area in which the act was committed (Otevřená společnost, 2018a). The ESSK has its own system of tactical and statistical classification (TSK). The TSK numbers represent specific types of crimes; for drug law offences there are five TSK numbers: 635, 641, 642, 636, and 643. Otevřená společnost (2018b) describes the connection of the ESSK to the Penal Code as follows: one TSK may cover several sections of the Code and, vice versa, one section of the Code may be statistically divided into several TSKs.

The NPC statistics offer a different perspective on drug crime from the ESSK data because they use a different collection method (Zeman et al., 2015). The biggest difference lies in data collection and specificity. The NPC collects data on the basis of monthly reports by all the relevant police and customs units concerning cases of primary drug crime where a police file was created that relates to criminal proceedings initiated after a perpetrator's arrest or the confiscation of illegal substances (Zeman et al., 2015). Regarding specificity, the NPC statistics include the type and amount of the substance (Mravčík et al., 2008). Furthermore, in addition to "primary drug crime", the NPC also covers the criminal acts of the production and handling of hormonally active substances as per Section 288 of the Penal Code (Mravčík et al., 2017).

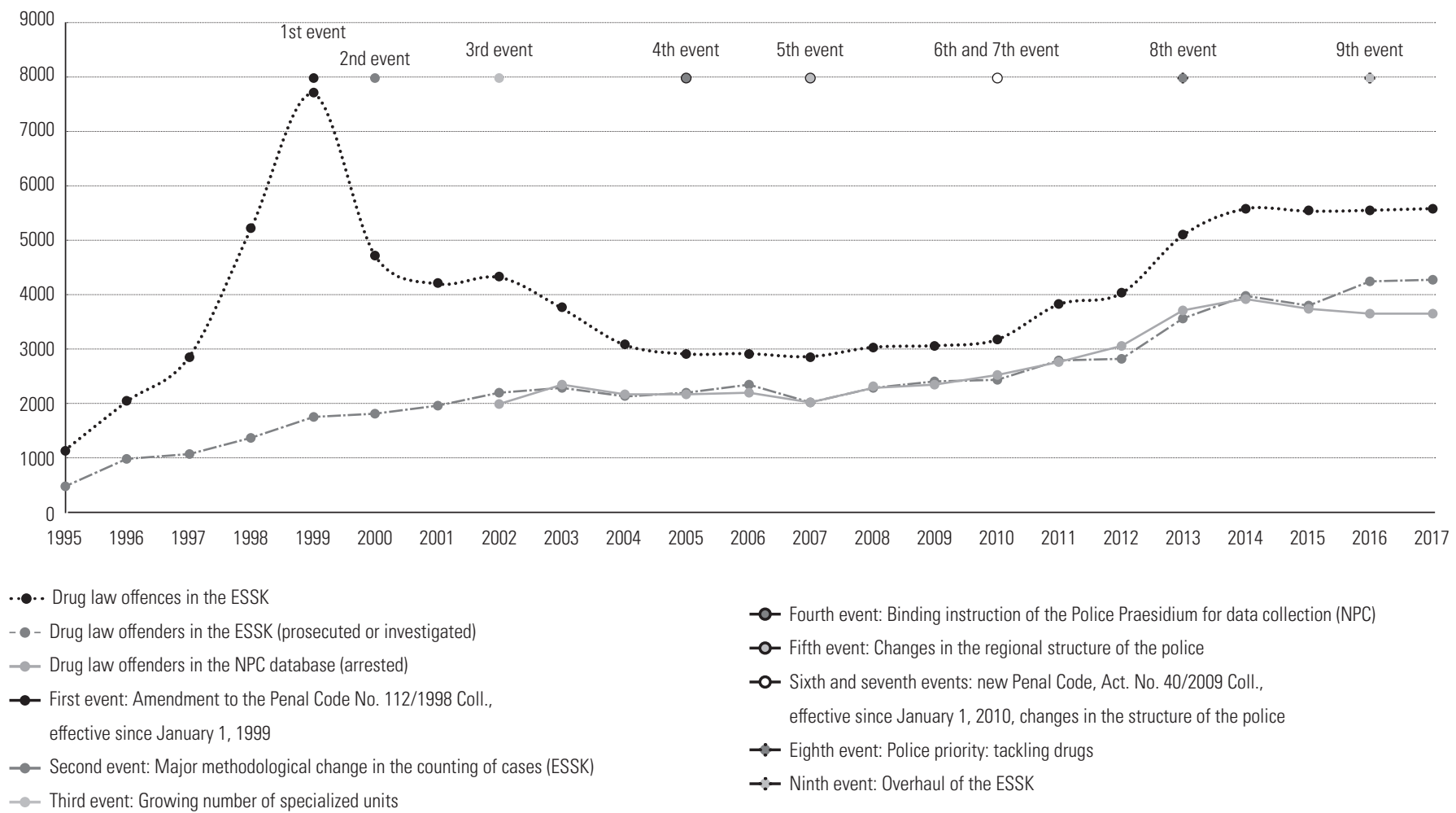

Figure 1 | The number of primary drug-related crimes in the ESSK, number of arrestees in the ESSK, number of arrestees in the NPC data (sources: Zábranský et al., 2001 and Mravčík et al., 2018), and significant events related to the monitoring system 


\subsection{Data collection and its context}

This section of the article focuses on those aspects of data collection and its context that might influence the indicators but were not identified as changes on the timeline. Regarding institutional and organizational culture, one of the aspects of the ESSK that might influence the data is the fact that it is not simply a tool to monitor the criminal situation, but that it also serves as a criterion for the evaluation of the efficiency of the police (Marešová, 2011), which might affect the practical and tactical approach to entering data into the database. For example, Miovský et al. (2001) mention the efforts of the higher ranks in the police force to lower the number of recorded drug law offences. Data collection in large organizations might be influenced by local differences. It has been reported that a unified approach to crime reporting has not been used across all regions, although it must be noted that the number of individuals prosecuted was reported using a unified methodology (Mravčík et al., 2005). For example, the number of criminal acts was allegedly over-reported in the region of the Capital City, Prague. In our email communication, one of the experts also pointed out another shortcoming of the ESSK - the absence of a "unified identity". The same person may be involved in several cases at different times and in different police units in the same statistical year. If his or her identity is not unified under a single reference number, the same individual may be recorded multiple times under different IDs. Last but not least, the quality of the data collection and analysis is influenced by the data culture in this area. Both Marešová (2011) and Mravčík et al. (2003) found both the publications and the interpretation of this type of data to be of low quality. Zeman et al. (2015) highlight inappropriate sorting criteria for data reporting and a lack of clarity in calculating indicators. Mravčík et al. (2003) and Marešová (2011) mention the use of unsubstantiated and shallow claims and a lack of solid arguments. Another feature of this culture is the isolation of each data source. The police and other criminal justice statistics are not linked and are not yet compatible (Zeman et al., 2015).

\subsection{Significant changes related to the data collection and its context}

This section provides an overview of significant events with the potential to influence the time series. Figure 1 gives an overview of three time series and nine events that were identified in three different areas: legislative changes, the reporting system, and the structure and priorities.

\subsection{Legislative changes}

For the police-based statistics, the determining factor is what might be considered a criminal offence, as it might thus be included in the statistics. In the second half of the $20^{\text {th }}$ century, the main legislative document determining this was the Penal Code, Act No. 140/1961 Coll., which more or less adopted the previous legislation (Gajdošíková, 2001).
The offences defined by this document were: a) to produce, import or export, provide or receive for another person narcotics or poisons (Section 187), and b) to provide for oneself or receive an object designed for the unauthorized production of narcotics or poisons (ibid.). This was changed by Amendment to the Penal Code No. 175/1990 Coll., which removed the criminal sanction of drug possession for personal use (Gajdošíková 2001; Běláčková \& Štefunková, 2018).

It is significant because the first identified event, Amendment to the Penal Code No. 112/1998 Coll., made personal drug possession of a "greater than small amount" a criminal offence, while the possession of a small amount remained an administrative offence (Běláčková \& Štefunková, 2018); however, the amount was not specified. The "greater than small amount" was to be assessed by the judge, but for the police and prosecutors by-laws describing the threshold amount were put into practice (Běláčková \& Štefunková, 2018). Despite the fact that this change meant that a broader spectrum of acts was defined as a criminal offence, it does not seem to have had a direct and observable effect on both the ESSK time series. There is an increase in both time series, but it seems rather to be a continuation of previous trends. This notion is supported by the fact that this legislative change was intended to help the police in the process of proving criminal offences (Gajdošíková, 2001), but police officers evaluated this change ambiguously (Miovský et al., 2001).

The fifth event that might have had an impact on the time series is the introduction of a new Penal Code, Act. No. 40/2009 Coll.. One of the changes involved was the introduction of government decree No. 467/2009 Coll., specifying a "greater than small amount". Compared to the by-laws in the previous period, the threshold of a "greater than small amount" was set higher for the majority of drugs, thus potentially narrowing the spectrum of acts that might be considered a criminal offence (Běláčková \& Štefunková, 2018). Later on, the government decree was cancelled by the Constitutional Court and replaced by a unifying opinion of the Supreme Court (Tpjn 301/2013). This opinion lowered the threshold for only two drugs (Mravčík, 2015); thus, we do not include it among the major changes. Another change related to the Penal Code is the introduction of a new drug law offence: personal cultivation of "plant drugs" (Section 285), which was complemented by the introduction of a new TSK (no. 643) in the ESSK. This drug law offence was new in that it had not been specified before but it was considered as possession for personal use or as drug manufacturing (Běláčková \& Štefunková, 2018).

It might be concluded that the scope of criminalized activities has remained similar (Zeman et al., 2017). It is difficult to estimate the influence of the new legislation; however, the evidence suggests that there was no significant influence. In the year of its introduction, there was no observable change in the time series, which was followed by increases in the following years. However, according to Zeman et al. (2015), this increase rather reflects the priorities of the police. This is supported by the fact that the implementation of the leg- 
islation did not cause any significant shift from the previous approach in this area (ibid.).

\subsection{Changes in the reporting system}

The second event, the major change in the counting of cases in the ESSK, possibly caused an artificial decreasing trend in the number of recorded drug law offences, which is observable in the different trends in different time series. The change was in the reporting of the continuing offences, which consists of multiple different instances of offending which were reported as one offence after the change (Zeman et al., 2015). This change influenced not only drug law offences (Zábranský et al., 2002), but also overall registered crime (Zeman et al., 2015). This change is apparent in an example described by a police officer: “(...) they usually used to accept any demonstrable case of drug sales for statistical purposes (...) Then a different system was implemented and data was considered for each "aggrieved party" (...) in four-week periods. That means that when the distributor had ten customers and supplied them all with drugs for ten months, then there were one hundred facts. Then they made it even stricter; there was pressure to reduce the number of cases, and so now they regard each customer as one case (...)" (Miovský et al., 2001, p. 89). The duration of the influence of this change is not certain; however, we can assume that it had some influence until 2004. Triangulating the time series at its face value with other time series, we can observe similar trends since 2004.

The ninth event in this area is the general overhaul of the ESSK database (Police of the Czech Republic, 2018a), but it has not yet been described in detail. This event might have contributed to the increase in the newly emerging difference between the number of drug law offenders registered in the ESSK and in the NPC database. The fourth event, the binding instruction of the Police Praesidium No. 86/2006, which specified the details of statistical data collection for NPC data collection (Mravčík et al., 2008), does not seem to have had any significant effect on the time series.

\subsection{Change in the structure and priorities}

The third event, the growing number of specialized units (new NPC branch offices) (Mravčík et al., 2003), does not seem to have had a strong effect on the time series; however, we can observe a certain increase that might well be a continuation of trends. The fifth event, i.e. the change in the police structure on the level of lower organizational units (Police of the Czech Republic, 2018b), coincided with a decrease for the year in which the change occurred in all time series, which suggests that it might have had a temporary effect. The seventh event is also related to the police structure. The new police structure corresponded to the structure of the regions, and as a result, the number of police directorates rose from eight to 14 (Diblíková et al., 2016; Marešová, 2011). It is difficult to ascertain the influence of this change because in the year 2010, another event was identified (the new Penal Code, Act. No. 40/2009 Coll.); however, as in the case of the new Penal Code, we observe no effect in the year of the event.

It is difficult to provide the exact time point for the eighth event, the change in police priorities. The priority of tackling drugs appeared explicitly in official documents in 2013 (Zeman et al., 2017). However, this change reportedly took place around the time of the introduction of the new legislation in 2010 (Zeman et al., 2015). This change was identified in different areas: international police cooperation, which appeared in the 2012 official reports, and in the form of increasing personnel and material capacities (Zeman et al., 2015; Zeman et al., 2017). In 2013, the greatest increase among all the time series took place, which points to the fact that the event related to priorities had a significant effect. We can also assume that the increases in previous years were shaped by the shift in priorities. This is supported by the fact that the priorities of the police are considered a predictor of the number of recorded drug law offences, not only by scholars (Zeman et al. 2015) but also by the police themselves (NPC, 2010).

\section{DISCUSSION AND CONCLUSION}

The article provides a review of the basic data collection characteristics and identifies different aspects of data collection and its context that have the potential to influence the indicators of drug law offenders and arrests. Nine events with the potential to influence these indicators were identified in three areas: legislation, the reporting system, and the structure and priorities. These aspects and events are discussed with regard to the interpretation of the time series data and their use in the analysis.

The drug law offenders and offences time series are regarded as measures of drug market policing, similarly as in the studies by Cooper et al. (2005) and Friedman et al. (2011, 2006) or in some of the studies reviewed by DeBeck et al. (2017). These indicators capture how many drug law offences are recorded by the police and how many drug law offenders are prosecuted, investigated, or arrested by the police. The discussion of what the time series really capture is important for the analysis of all indicators. In this case the question is whether the time series reflect the trends of drug-related crime or the priorities of the police and their ability to record such crimes. In our study, we found that some of the changes related to the priorities of the police and thus to police resources and the ability of the police to record drug-related crime might have caused an increase in the indicators, which is in agreement with the body of literature in this area (Zeman et al., 2017; Hartnoll et al., 1989; Loughran \& McCann, 2001; Mounteney \& Griffiths, 2019; NPC, 2010).

The events related to the data collection and its context might be divided into two groups according to the way they might influence the time series. Group 1 (the first, third, sixth, and eighth events) has the potential to influence the 
policing of the drug market, police activity on drug markets, via changes in the priorities of the police, resources, and the scope of acts that might be criminalized. Group 2 (the second, fourth, and ninth events) has the potential to change the way in which data is collected and recorded. In the case of the fifth and seventh events, which group they belong to is open to discussion. However, the fifth event possibly influenced the policing of the drug market rather than data collection because a decrease is observable in both time series. In contrast, the influence of the ninth and second events from Group 2 was observable only in the time series from one data collection system. The Group 2 is significant for the long-term trend analysis of drug market policing because it will allow potential biases to be detected, while Group 1 is significant for the analysis of the factors that cause the intensification of the policing of the drug market. Furthermore, for the use of police statistics as a proxy measure of primary drug-related crime, Group 2 might be used as an overview of the changes biasing the data, which should be accounted for in the analysis.

The events from the second group are used to discuss whether, for the analysis of the policing of the drug market, the time series fulfil the assumptions of the time series methods, i.e. that data is recorded in the same manner throughout a given time period (Gilmour et al., 2006). The methodological change related to the drug law offences time series in 2000 violates this assumption. The use of this series is recommended from 2004 onwards because by triangulating this time series at its face value with other time series, we can observe similar trends in all time series since 2004, suggesting the reliability of the time series. The use of the ESSK drug law offenders time series is recommended only until 2016 because the reconstruction of the ESSK might have biased the data. To conclude, with regard to the long-term trend analysis, we discuss the best choices for the analysis. The ESSK provides longer time series; however, the assumption of stable data recording practices is violated. The NPC data on drug law offenders provides better specificity, is more stable in comparison with other time series, and seems unaffected by methodological changes, thus making it the best fit for use in the analysis of longterm trends.

This article also provides the basis for other methodological and analytical decisions. Deciding which data set is the best fit for analysis of "primary drug crime", we can apply the criteria of specificity of Mounteney et al. (2010). The NPC's data collection, in contrast to the ESSK, has better specificity, providing information on the type of substance. Another important analytical decision is the selection of the time and space units, which are basic units in time-series analysis but also in other approaches. When selecting the space unit, it is important to find out if there are regional differences in data collection. Taking the country as the basic unit, significant regional changes in data collection might distort overall trends or, if there are bigger regional differences in data collection, analyses that focus on regional differences, such as comparative analyses of regions, are not an appropriate approach. As already noted, a unified approach to the reporting of drug offences was not applied across all regions, although it must be said that the number of drug law-offending individuals was reported using a unified methodology (Mravčík et al., 2005), and thus the drug law offenders time series is more suitable for a regional or country-level analysis. When using more than one time series in the analysis, it is also important to estimate the lag between events and their recording in the data collection system. In this case, incidents are entered into the police databases after criminal proceedings have been initiated, suggesting a shorter lag.

The recommendations for the improvement of data collection and its context are as follows. Investigations regarding the reliability and validity of the data should be carried out. Qualitative interviews with police officers focused on the practices of data production would help to evaluate the overall system. For example, information on the local specifics of data collection could be provided. Another possible approach in this direction is an analysis of police case files. This analysis should focus on the the application of the law, e.g. what types of cases are recorded under different categories, for example sections of the penal law, and whether this changes over time. Furthermore, there is some room for improvement in data culture, for example regarding the publication of materials related to data and indicators such as criteria for data reporting and procedures for calculating indicators. It is important to record changes in the data collection as specifically as possible and to publish them regularly. Concerning data collection, we recommend increasing the specificity of the ESSK; the type of drug should be recorded for each incident. It is also recommended that a link between police statistics and other criminal justice statistics is provided.
Ethics approval and consent to participation: Not applicable. The article adheres to the Farmington Consensus 2.1.

Authors' contributions: $\mathrm{BP}$, together with $\mathrm{MB}$, drafted the design of the research. BP drafted the initial manuscript. MB provided a substantial revision of the manuscript. Both authors have read and approved the final manuscript
Declaration of interest: No conflict of interest 


\section{REFERENCES}

Aebi, M., Akdeniz, G., Barcley, G., Campistol, C., Caneppele, S., Gruszczynka, B., Harrendorf, S., Heiskanen, M., Hysi, V., Jehle, J.-M., Jokinen, A., Kensey, A., Killias, M., Lewis, C., Savona, E., Smit, P., Bórisdóttir, R. (2014). European Sourcebook of Crime and Criminal Justice Statistics 2014. European Institute for Crime Prevention and Control, Helsinki.

Belackova, V., Stefunkova, M., 2018. Interpreting the Czech drug decriminalization: The glass is half full - Response to Cerveny, J., Chomynova, P., Mravcik, V., \& van Ours, J.C. (2017). Cannabis decriminalization and the age of onset of cannabis use. International Journal of Drug Policy 52, 102-105. https://doi.org/10.1016/j.drugpo.2017.10.010

BJS, 2019. Law Enforcement [WWW Document]. URL https://www.bjs.gov/ index.cfm?ty=tp\&tid=7

Blankenship, K.M., Koester, S., 2002. Criminal Law, Policing Policy, and HIV Risk in Female Street Sex Workers and Injection Drug Users. The Journal of Law, Medicine and Ethics 30, 548-559. https://doi.org/10.1111/j.1748-720X.2002. tb00425.x

Bohnert, A.S.B., Nandi, A., Tracy, M., Cerdá, M., Tardiff, K.J., Vlahov, D., Galea, S., 2011. Policing and risk of overdose mortality in urban neighborhoods. Drug and Alcohol Dependence 113, 62-68. https://doi.org/10.1016/j. drugalcdep.2010.07.008

Booth, R.E., Dvoryak, S., Sung-Joon, M., Brewster, J.T., Wendt, W.W., Corsi, K.F., Semerik, O.Y., Strathdee, S.A., 2013. Law Enforcement Practices Associated with HIV Infection Among Injection Drug Users in Odessa, Ukraine. AIDS and Behaviour 17, 2604-2614. https://doi.org/10.1007/s10461-013-0500-6

Burris, S., Blankenship, K.M., Donoghoe, M., Sherman, S., Vernick, J.S., Case, P., Lazzarini, Z., Koester, S., 2004. Addressing the "Risk Environment" for Injection Drug Users: The Mysterious Case of the Missing Cop. Milbank Quarterly 82, 125-156. https://doi.org/10.1111/j.0887-378X.2004.00304.x

Cooper, H.L.F., Wypij, D., Krieger, N., 2005. Police drug crackdowns and hospitalisation rates for illicit-injection-related infections in New York City. International Journal of Drug Policy 16, 150-160. https://doi.org/10.1016/j.drugpo.2005.03.001

Csete, J., Kamarulzaman, A., Kazatchkine, M., Altice, F., Balicki, M., Buxton, J., Cepeda, J., Comfort, M., Goosby, E., Goulão, J., Hart, C., Kerr, T., Lajous, A.M., Lewis, S., Martin, N., Mejía, D., Camacho, A., Mathieson, D., Obot, I., Ogunrombi, A., Sherman, S., Stone, J., Vallath, N., Vickerman, P., Zábranský, T., Beyrer, C., 2016. Public health and international drug policy. The Lancet387, 1427-1480. https://doi.org/10.1016/S0140-6736(16)00619-X

DeBeck, K., Cheng, T., Montaner, J.S., Beyrer, C., Elliott, R., Sherman, S., Wood, E., Baral, S., 2017. HIV and the criminalisation of drug use among people who inject drugs: a systematic review. The Lancet HIV 4, e357-e374. https://doi.org/10.1016/S2352-3018(17)30073-5

Diblíková, S., Cejp, M., Štefunková, M., Zeman, P., Smejkal, V., Martinková, M., 2016. Analýza trendů kriminality v České republice v roce 2015.

Institut pro kriminologii a sociální prevenci, Praha.

Dixon, D., Maher, L., 2005. Policing, crime and public health: Lessons for Australia from the 'New York miracle.' Criminal Justice 5, 115-143. https://doi.org/10.1177/1466802505053494

EMCDDA, 2018. Drug law offences [WWW Document]. URL http://www.emcdda.europa.eu/data/stats2019/dlo

Fitzgerald, J.L., 2005. Policing as public health menace in the policy struggles over public injecting. International Journal of Drug Policy 16, 203-206. https://doi.org/10.1016/j.drugpo.2005.06.010

Friedman, S.R., Cooper, H.L., Tempalski, B., Keem, M., Friedman, R., Flom, P.L., Des Jarlais, D.C., 2006. Relationships of deterrence and law enforcement to drugrelated harms among drug injectors in US metropolitan areas. AIDS 20, 93-99.

Friedman, S.R., Pouget, E.R., Chatterjee, S., Cleland, C.M., Tempalski, B., Brady, J.E., Cooper, H.L.F., 2011. Drug Arrests and Injection Drug Deterrence. American Journal of Public Health 101, 344-349. https://doi.org/10.2105/ AJPH.2010.191759
Gajdošíková, H., 2001. Nástin historie právní úpravy drogových trestných činů na historickém území Čech, Moravy a Slezska. Adiktologie 1, 14-21.

Gilmour, S., Degenhardt, L., Hall, W., Day, C., 2006. Using intervention time series analyses to assess the effects of imperfectly identifiable natural events: a general method and example. BMC Med Res Methodo/ 6, 16. https://doi.org/10.1186/1471-2288-6-16

Griffiths, P., Vingoe, L., Hunt, N., Mounteney, J., Hartnoll, R., 2000. Drug Information Systems, Early Warning, and New Drug Trends: Can Drug Monitoring Systems Become More Sensitive to Emerging Trends in Drug Consumption? Substance Use \& Misuse 35, 811-844. https://doi.org/10.3109/10826080009148423

Hartnoll, R., Hendriks, V. M., Morrival, M. (1998). The Assessment of Drug Problems. WHO Regional Office for Europe, Copenhagen.

Kerr, T., Small, W., Wood, E., 2005. The public health and social impacts of drug market enforcement: A review of the evidence. International Journal of Drug Policy 16, 210-220. https://doi.org/10.1016/j.drugpo.2005.04.005

Kilmer, B., Reuter, P., Giommoni, L., 2015. What Can Be Learned from CrossNational Comparisons of Data on Illegal Drugs? Crime and Justice 44, 227-296. https://doi.org/10.1086/681552

Kiššová, L., Mravčík, V., Chmelová, E., Dárek, D., 2014. Souhrnná zpráva o realizaci protidrogové politiky v krajích v r. 2012. Sekretariát Rady vlády pro koordinaci protidrogové politiky, Praha.

Lopez Bernal, J., Cummins, S., Gasparrini, A., 2016. Interrupted time series regression for the evaluation of public health interventions: a tutorial. International Journal of Epidemiology. https://doi.org/10.1093/ije/dyw098

Maher, L., 1999. Policing and public health: Law enforcement and harm minimization in a street-level drug market. British Journal of Criminology, 39 488-512. https://doi.org/10.1093/bjc/39.4.488

Marešová, A., 2011. Resortní statistiky-základní zdroj informací o kriminalitě $\checkmark$ České republice. Institut pro kriminologii a sociální prevenci.

Marešová, A., 2010. Jsou statistické údaje dostatečným zdrojem informací a stavu a vývoje kriminality v ČR? Kriminalistika 21, 3-11.

McGallagly, J., McKeganey, N., 2013. Does robust drug enforcement lead to an increase in drug users coming forward for treatment? Drugs: Education, Prevention and Policy 20, 1-4. https://doi.org/10.3109/09687637.2012.733980

Minařík, J., Zahradník, M., 2003. Zhodnocení situace v Pardubickém kraji. Unpublished.

Miovský, M., Gajdošíková, H., Skutilová, K., Zábranský, T., Bullington, B., 2001. Přehled výsledků substudie provedené s policisty, vyšetřovateli, kriminalisty a soudci ve vztahu k trestné činnosti uživatelů nelegálních drog: kvalitativní analýza. Adiktologie, 1, 81-96.

Mounteney, J., Fry, C., McKeganey, N., Haugland, S., 2010. Challenges of Reliability and Validity in the Identification and Monitoring of Emerging Drug Trends. Substance Use \& Misuse 45, 266-287. https://doi.org/10.3109/10826080903368598

Mravčík, V., 2015. (De)criminalisation of possession of drugs for personal use A view from the Czech Republic. The International Journal of Drug Policy 26(7), 705.

Mravčík, V., Chomynová, P., Grohmannová, K., Janíková, B., Černíková, T., Rous, Z., Tion Leštinová, Z., Kiššová, L., Nechanská, B., Vlach, T., Fidesová, H., Vopravil, J., 2018. Annual Report on the Drug Situation 2017 - Czech Republic. Úřad vlády České republiky, Praha.

Mravčík, V., Chomynová, P., Grohmannová, K., Janíková, B., Grolmusová, L., Tion Leštinová, Z., Rous, Z., Kiššová, L., Nechanská, B., Sopko, B., Vlach, T., Fidesová, H., Jurystová, L., Vopravil, J., Malinová, H., 2015. Annual Report on the Drug Situation 2014 - Czech Republic. Úrad vlády České republiky, Praha.

Mravčík, V., Chomynová, P., Grohmannová, K., Janíková, B., Rous, Z., Tion Leštinová, Z., Kiššová, L., Nechanská, B., Vlach, T., Fidesová, H., Vopravil, J., 
Černíková, T., Kozák, J., 2017. Annual Report on the Drug Situation 2016 - Czech Republic. Úřad vlády České republiky, Praha.

Mravčík, V., Chomynová, P., Grohmannová, K., Nečas, V., Grolmusová, L., Kiššová, L., Nechanská, B., Sopko, B., Fidesová, H., Vopravil, J., Jurystová, L., 2014. Annual Report on the Drug Situation 2013 - Czech Republic. Úřad vlády České republiky, Praha.

Mravčík, V., Chomynová, P., Orlíková, B., Pešek, R., Škařupová, K., Škrdlantová, E., Miovská, L., Gajdošíková, H., Vopravil, J., 2008. Annual Report on the Drug Situation 2007 - Czech Republic. Úřad vlády České republiky, Praha.

Mravčík, V., Korčišová, B., Lejčková, P., Miovská, L., Škrdlantová, E., Petroš, O., Sklenár, V., Vopravil, J., 2005. Annual Report on the Drug Situation 2004 - Czech Republic. Úřad vlády České republiky, Praha.

Mravčík, V., Zábranský, T., Korčišová, B., Lejčková, P., Škrdlantová, E., Štastná, L., Macek, V., Petroš, O., Gajdošíková, H., Miovský, M., Kalina, K., Vopravil, J., 2003. Annual Report on the Drug Situation 2002 - Czech Republic. Úrad vlády České republiky, Praha.

National Drug Headquarters, 2018. Výroční zpráva 2017.

Národní protidrogová centrála, 2010. Výroční zpráva 2009.

Otevřená společnost, 2018a. mapa kriminality [WWW Document]. URL http://www.mapakriminality.cz/o-aplikaci/

Otevřená společnost, 2018b. 0 projektu [WWW Document]. URL http://www.mapakriminality.cz/o-aplikaci/\#0AplikaciData

Police of the Czech Republic, 2018a. STATISTIKY [WWW Document]. URL http://www.policie.cz/clanek/archiv-statistiky-statisticke-prehledykriminality.aspx.

Police of the Czech Republic, 2018b. KRIMINALITA [WWW Document]. URL http://www.policie.cz/statistiky-kriminalita.aspx

Přecechtěl, P., 2013. Sekundární drogová kriminalita - co o ní víme, respektive co o ní můžeme vědět? In Zoubková, I., Firstová, J., (Eds.), Kriminologie: aktuální problémy. Policejní akademie ČR, Praha, 182-188.
Sarang, A., Rhodes, T., Sheon, N., Page, K., 2010. Policing Drug Users in Russia: Risk, Fear, and Structural Violence. Substance Use \& Misuse 45, 813-864. https://doi.org/10.3109/10826081003590938

Secretariat of the Government Council for Drug Policy Coordination, 2019. Czech Drug Policy and Its Coordination: Evidence-based Addiction Policy [WWW Document]. URL https://www.vlada.cz/assets/ppov/protidrogova-politika/ GCDPC_information_1.pdf

Small, W., Kerr, T., Charette, J., Schechter, M.T., Spittal, P.M., 2006. Impacts of intensified police activity on injection drug users: Evidence from an ethnographic investigation. International Journal of Drug Policy 17, 85-95. https://doi.org/10.1016/j.drugpo.2005.12.005

Strathdee, S.A., Hallett, T.B., Bobrova, N., Rhodes, T., Booth, R., Abdool, R., Hankins, C.A., 2010. HIV and risk environment for injecting drug users: the past, present, and future. The Lancet 376, 268-284. https://doi.org/10.1016/S0140-6736(10)60743-X

Tabachnick, B.G., Fidell, L.S., Ullman, J.B., 2019. Using multivariate statistics. Boston, MA: Pearson.

Zábranský, T., Csémy, L., Gajdošíková, H., Korčišová, B., Kuda, A., Miovský, M., Mravčík, V., Petroš, O., Radimecký, J., Vopravil, J., 2002. Annual Report on the Drug Situation 2001 - Czech Republic. Úřad vlády ČR, Praha.

Zábranský, T., Mravčík, V., Gajdošíková, H., Miovský, M., 2001. PAD: impact analysis project of New Drugs Legislation. Office of the Czech Government, Secretariat of the National Drug Commission, Prague.

Zeman, P., Gajdošíková, H., 2010. Nový trestní zákoník. Zaostřeno 8, 1-12.

Zeman, P., Štefunková, M., Trávníčková, I., 2017. Increase in Figures on Drug Offences in the Czech Republic: An Epidemic of Drug Crime or Something Else? Czech Criminology 2017, 13.

Zeman, P., Štefunková, M., Trávníčková, I., 2015. Drogová kriminalita a trestní zákoník. Institut pro kriminologii a sociální prevenci. Institut pro kriminologii a sociální prevenci, Praha. 